\title{
Osteosarcoma: correlation between radiological and histological changes after intra-arterial chemotherapy
}

\author{
J.I. Bilbao ${ }^{1}$, S. Martín Algarra ${ }^{2}$, J. Martínez de Negri $^{3}$, F. Lecumberri ${ }^{1}$, J. Longo ${ }^{1}$, L. \\ Sierrasesúmaga $^{4}$ and J. Cañadell ${ }^{3}$ \\ Departments of ${ }^{1}$ Radiology, ${ }^{2}$ Oncology, ${ }^{3}$ Orthopedic Surgery, and ${ }^{4}$ Pediatrics, Clínica \\ Universitaria de Navarra, Pamplona, Spain
}

Address for reprints: J.I. Bilbao.

Department of Radiology, Clínica Universitaria de Navarra. Avda. Pio XII s/nº, Pamplona 31080, Spain.

\begin{abstract}
The statistical correlation between three different radiological methods (conventional radiography, computed tomography and angiography) and tumor necrosis (TN) of the resected specimen have been studied in a series of 31 patients diagnosed with osteosarcoma (OS). They were treated with a multidisciplinary approach including intraarterial and intravenous chemotherapy followed by limb salvage procedures, plus intraoperative radiotherapy and adjuvant chemotherapy. A clear statistical correlation has been obtained between TN and angiography $(\mathrm{p}=0.02)$ and between TN and two specific radiological signs: "tumoral stain and neovascularity" $(p=0.02)$ and "peritumoral fat planes" $(\mathrm{p}=0.05)$. Conventional radiography, computed tomography and other radiological signs studied (nutrient vessel, soft tissue mass and central peripheral calcifications) did not show any significant correlation with TN. These results seem to suggest that angiography is a method to evaluate TN preoperatively and also to define the efficacy of neoadjuvant chemotherapy in OS.
\end{abstract}

\section{KEY WORDS}

Osteosarcoma, efficacy study; Osteosarcoma, radiography; Osteosarcoma, therapy 


\section{INTRODUCTION}

Recently published reports have demonstrated that osteosarcoma (OS) responds to neoadjuvant intraarterial (i.a.) and intravenous (i.v.) chemotherapy [8,12, 17], allowing limb salvage procedures. A variety of drugs including either adriamycin (ADM), cisplatin (CDDP) and methotrexate (MTX) in different regimens have been reported.

The efficacy of neoadjuvant chemotherapy has been related to the degree of tumor necrosis (TN) obtained in the tumor specimen [10]. The grade of TN has been suggested to have prognostic significance regarding survival [17].

The grading of TN prior to surgery was attempted through clinical, radionuclide and radiographic studies, which was correlated with the histopathology of the tumor.

The purpose of this study is to assess the predictive value of TN by conventional radiography, CT and angiography preoperatively.

\section{MATERIAL AND METHODS}

From April 1983 to January 1988, 31 patients with histopathological diagnosis of OS were treated with a multidisciplinary approach including i.a. and i.v. neoadjuvant chemotherapy followed by limb salvage surgery plus intraoperative radiotherapy and adjuvant chemotherapy.

Intraarterial chemotherapy was administered immediately after the histological diagnosis and consisted of the administration of CDDP $40 \mathrm{mg} / \mathrm{m}^{2}$ daily on three alternative days repeated every 3 weeks. The total dose of CDDP by i.a. route was 360 $\mathrm{mg} / \mathrm{m}^{2}$.

CDDP was infused over a 2-5 min period with the tip of the catheter placed in the artery(ies) that supplied the tumor; when this was technically impossible since there were various arteries supplying the tumor, a tourniquet was applied distally to the tumor during the infusion time.

Tumor necrosis was evaluated according to the Mavligit scale, and a careful histopathological study of the resected specimen with regard to necrosis and regenerative changes [10] was performed. On this scale, grade I was defined as a $0-20 \%$ $\mathrm{TN}$, grade II was $20-40 \% \mathrm{TN}$, grade III was $40-60 \% \mathrm{TN}$, grade IV was $60-90 \% \mathrm{TN}$ and grade $\mathrm{V}$ was $90-99 \% \mathrm{TN}$.

The radiologic criteria are explained in Table 1. Tumor response to i.a. treatment has been evaluated radiologically by conventional radiography, computed tomography (without intravenous infusion of contrast) and angiography.

\section{RESULTS}

The characteristics of the 31 patients are shown in Table 2. Two patients were not analyzed for correlation; one refused surgical treatment and the other had experienced almost complete tumor excision with previous surgery.

The total number of i.a. chemotherapy procedures was 255, with a mean of 8.22 per patient. Complications were observed in vine cases $(3.5 \%$ of the total number of procedures): thrombosis of the common femoral artery (3 cases), stenosis of the common femoral artery (1 case), reversible arterial spasm (3 cases), arterial dissection of the common femoral artery (1 case) and localized dermatitis at the infused area (1 case). None of these complications required surgical treatment. 
Table 3 shows the TN observed in the resected bone after i.a. chemotherapy; 16 patients (52\%) achieved more than 90\% histologic tumor necrosis. All patients were treated with conservative surgery (non-amputative) through bone replacement with allografts or articular prosthesis.

Correlation between TN and radiological changes evaluated with different methods is presented in Table 4. In this Table, a significant correlation can be observed between the degrees achieved for TN and angiography (Fig. 1) and especially with the angiographic sign "tumoral stain and neovascularity" (Fig. 2). An important statistical correlation is also observed with the CT sign "Peritumoral fat planes". The other radiological findings, such as tumoral calcification, although dramatic in some instances (Fig. 3) do not present good correlation with tumor necrosis (Fig. 4).

\section{DISCUSSION}

The use of neoadjuvant chemotherapy in patients with OS helps to improve the local tumor extension, allowing limb salvage procedures. As has been previously stressed [17], post-chemotherapeutic TN may have statistical value regarding survival. Thus, the assessment of TN preoperatively may have indications regarding the requirement and the design of new, more active protocols.

A major goal of diagnostic radiology would be to establish the criteria of response that correlate with pathological changes.

Several authors have analyzed the changes observed in conventional radiography after chemotherapy $[3,4,14,15]$. The main criteria analyzed have been disappearance of softtissue mass and increase in central and peripheral calcification. They conclude that conventional radiography is an accurate method in predicting the histological response. Two series have correlated the conventional radiographic and CT findings with histopathological changes. These authors obtained a better definition of soft-tissue mass in relation to the surrounding planes, and a superior contrast resolution favoring the use of CT $[9,14]$.

Angiographically the most important finding is the presence of neovascularity and tumoral stain $[3,6,7]$. Chuang has observed a good correlation between the degree of neovascularization and the histological response [2]. In a series of 22 osteosarcomas, Kumpan presented similar results although, in his opinion, the absence of tumor vascularization did not indicate absence of tumor [7]. This author also stressed the point that various circumstances, such as pathological fractures, can mimic tumor vascularization [6]. We have observed a similar problem in patients that had a Wagner external fixator which increased vascularization.

In this series, we observed a good prediction of tumor necrosis by angiography, mainly correlated with the disappearance of "neovascularity and tumoral stain" (Figs. 1 and 2). No correlations were observed between the plain radiographs (Fig. 3) and CT (Fig. 4). These unexpected results are attributable to the fact that certain findings such as the presence of peripheral calcifications and also the decrease in tumor mass alone did not have any correlation with TN. In our opinion, CT will yield information mainly concerning the presence of peritumoral fat planes and good delineation of the tumoral mass.

Despite general agreement in the ability of Magnetic Resonance (MR) in the initial staging of bone-tumor lesions [1], its role in evaluating treatment-induced changes is doubtful. In particular, MR is not specific for areas of residual viable tumor after preoperative chemotherapy [11]. MR was unsuccessful in defining peripheral areas of 
residual tumor, post-treatment calcification or the percentage of viable tumor after treatment. In a recent study [13], it has been stressed that MR cannot predict the percentage of tumor necrosis "because of an overlap in appearances of viable tumor, tumor necrosis, edema, fibrosis and haemorrhage".

The main limitation resides in the poor specificity in differentiating active tumor from treatment-induced changes [16].

Clearly, further experience and understanding of these severe limitations are mandatory and will help to define the future role of MR in bone tumors treated with chemotherapy. According to our results, and with the analysis of other recent series [2], we suggest that digital angiography is a good method in defining tumor response to neoadjuvant chemotherapy and also in evaluation of the degree of TN preoperatively.

\section{REFERENCES}

1. Bloem JL, Bluemm RG, Taminiau Ahm, Van Oosterom AT, Stolk J, Doornbos J. Magnetic resonance imaging of primary malignant bone tumors. Radiographics 1987; 7: 425.

2. Chuang VP, Benjamin R, Jaffe M, Wallace S, Ayala AG, Murray J, Charnsangavej C, Soo CS. Radiographic and angiographic changes in osteosarcoma after intra-arterial chemotherapy. AJR 1982; 139: 1065.

3. Den Heeten GJ, Thijn CJP, Kamps WA, Koops HS, Oosterhuis JW, Oldhoff J. The effect of chemotherapy on osteosarcoma of the extremities as apparent from conventional roentgenograms. Pediat Radiol 1986; 16: 407.

4. Kumpan W, Lechner G, Wittich GR, Salzer-Kuntschik M, Delling G, Kotz R, Hajek P, Sedera J. The angiographic response of osteosarcoma following preoperative chemotherapy. Skelet Radio] 1986; 15: 96,

5. Lechner G. Salzer-Kuntschik M, Kumpan W, Kotz R. Engel A, Sekera J. Angiographic-pathologic comparison in osteosarcoma after presurgical chemotherapy. J Cancer Res Clin Oncol 1983; 106 (Suppl): 51.

6. Link MP, Goorin AM, Miser AW, Green AA, Pratt CB, Belasco JB, Pritchard J, Malpas JS , Baker AR, Kirkpatrick JA, Ayala AG, Shuster JJ, Abelson HT, Simone JV, Vietti JV. The effect of adjuvant chemotherapy on relapse-free survival in patients with osteosarcoma of the extremity. M Engl J Med 1986; 314: 1600.

7. Mail JT, Cohen MD, Mirkin LD, Provisor AJ. Response of osteosarcoma to preoperative intravenous high-dose methotrexate chemotherapy: CT evaluation. AJK 1985; 144: 89.

8. Mavligit GM, Benjamin R, Patt YZ, Jaffe N, Chuang V, Wallace S, Murray J, Ayala A, Johnston S, Hersh EM, Calvo DB Intraarterial cisplatinum for patients with inoperable skeletal tumors. Cancer 1981; 48: 1.

9. Pan G, Raymond AK, Carrasco CH, Wallace S, Shirkhoda A, Kim EE, Jaffe N, Murray JA, Benjamin RS. MR imaging of osteosarcomas following preoperative chemotherapy. Radiology 1988; 169 (P) Suppl: 24.

10. Rosen G, Caparros B, Huvos AG, Kosioff C, Nirenberg A, Cacavio A, Marcove R, Lane J, Mehta B, Urban C. Preoperative chemotherapy for osteogenic sarcoma: selection of postoperative adjuvant chemotherapy based on the response of the primary tumor to preoperative chemotherapy. Cancer 1982; 49: 1221. 
11. Sanchez RB, Quinn SF, White V, Estrada J, Walling A, Greenberg HM. Musculoskeletal neoplasms after intraarterial chemotherapy: pathologic correlation with MR imaging. Radiology 1988; 169 (P). Suppl: 24.

12. Shirkhoda A, Jaffe N, Wallace S, Ayala A, Lindell MM, Zornoza J. Computed tomography of osteosarcoma after intra-arterial chemotherapy. AJR 1985; 144 : 95.

13. Smith J, Heelan RT, Huvos AG, Caparros B, Rosen G, Urmacher C, Caravelli JF. Radiographic changes in primary osteosarcoma following intensive chemotherapy. Radiology 1982; 143: 355.

14. Vanel D, Coffre C, Covanet D, Meunier M, Contesso G, Missenard G. Potpourri of limitations and pitfalls of MR imaging in primary muskuloskeletal tumors. Radiology 1988; 169 (P) Suppl: 23.

15. Wallace S, Carrasco CH, Charnsangavej CH, Lee YY, Ulright K, Gianturco C. Percutaneous transcatheter infusion and infarction in the treatment of human cancer: part II. In: Current Problems in Cancer Vol. VIII, chapter 18, 1984; 4. 


\begin{tabular}{|c|c|c|c|c|}
\hline \multicolumn{5}{|c|}{ Table 1. Radiologic criteria or response* } \\
\hline & & Conventional radiology & CT & Angiography \\
\hline \multirow{3}{*}{ I } & \multirow{3}{*}{$\begin{array}{l}\text { Tumoral } \\
\text { progression }\end{array}$} & Increase in soft tissue mass & $\begin{array}{l}\text { Increase in soft tissue } \\
\text { mass }\end{array}$ & $\begin{array}{c}\text { Tumoral stain more } \\
\text { than } 50 \%\end{array}$ \\
\hline & & $\begin{array}{l}\text { Increase in bone } \\
\text { destruction }\end{array}$ & $\begin{array}{c}\text { Increase in bone } \\
\text { destruction }\end{array}$ & $\begin{array}{l}\text { No changes in } \\
\text { vascular supply }\end{array}$ \\
\hline & & & $\begin{array}{l}\text { Poor definition of fat } \\
\text { planes }\end{array}$ & \\
\hline II & No changes & No changes & No changes & $\begin{array}{l}20-50 \% \text { of residual } \\
\text { stain }\end{array}$ \\
\hline \multirow[b]{2}{*}{ III } & \multirow[b]{2}{*}{$\begin{array}{l}\text { Moderate } \\
\text { response }\end{array}$} & $\begin{array}{l}\text { Some decrease in soft } \\
\text { tissue mass }\end{array}$ & $\begin{array}{l}\text { Some decrease in soft } \\
\text { tissue mass }\end{array}$ & $\begin{array}{l}0-20 \% \text { of } \\
\text { persistence in } \\
\text { tumoral stain }\end{array}$ \\
\hline & & $\begin{array}{l}\text { Some increase in } \\
\text { calcification }\end{array}$ & $\begin{array}{c}\text { Some increase in } \\
\text { calcification. } \\
\text { Better definition of fat } \\
\text { planes }\end{array}$ & $\begin{array}{l}\text { Marked decrease in } \\
\text { the size of } \\
\text { supplying vessels }\end{array}$ \\
\hline \multirow{3}{*}{ IV } & \multirow{3}{*}{$\begin{array}{l}\text { Excellent } \\
\text { response }\end{array}$} & $\begin{array}{l}\text { Marked decrease in soft } \\
\text { tissue mass }\end{array}$ & $\begin{array}{l}\text { Marked decrease in } \\
\text { soft tissue mass }\end{array}$ & $0 \%$ of tumoral stain \\
\hline & & $\begin{array}{c}\text { Marked increase in } \\
\text { peripheral or central } \\
\text { calcification }\end{array}$ & $\begin{array}{c}\text { Marked increase in } \\
\text { peripheral or central } \\
\text { calcification } \\
\end{array}$ & $\begin{array}{l}\text { Normalization in } \\
\text { size of supplying } \\
\text { vessels }\end{array}$ \\
\hline & & $\begin{array}{l}\text { Excellent visualization of } \\
\text { fat planes }\end{array}$ & & \\
\hline
\end{tabular}




\begin{tabular}{|l|c|}
\hline \multicolumn{2}{|c|}{ Table 2. Characteristics of patients } \\
\hline Patients \\
\hline Total & 31 \\
\hline Analyzed & 29 \\
\hline Age (years) & $7-39$ \\
\hline Range & 16 \\
\hline Median & 11 \\
\hline Sex & 20 \\
\hline Male \\
\hline Female \\
\hline Karnofsky* \\
\hline$>60 \%$ & 24 \\
\hline \begin{tabular}{l}
$<60 \%$ \\
\hline Lung metastases
\end{tabular} \\
\hline Yes & 7 \\
\hline No & 24 \\
\hline $\begin{array}{l}\text { *Karnofsky scale [5] measures the “quality of } \\
\text { life”. Patients under 60\%; cannot manage without } \\
\text { assistance, mostly due to a pathological fracture. }\end{array}$ \\
\hline
\end{tabular}

Table 3. Tumoral necrosis after intraarterial chemotherapy

\begin{tabular}{|c|c|}
\hline Grade V & 16 \\
\hline Grade IV & 7 \\
\hline Grade III & 5 \\
\hline Grade II & 3 \\
\hline Grade I & 0 \\
\hline
\end{tabular}




\begin{tabular}{|l|c|}
\hline \multicolumn{2}{|c|}{$\begin{array}{c}\text { Table 4. Grading correlation between radiological } \\
\text { and histopathological findings }\end{array}$} \\
\hline Grade of 'Mavligit scale' & p \\
\hline Conventional radiography & 0,19 \\
\hline CT & 0,29 \\
\hline Angiography & 0,02 \\
\hline Nutritious vessel & 0,09 \\
\hline Tumoral stain & 0,02 \\
\hline Soft tissue mass & 0,22 \\
\hline Fat planes & 0,05 \\
\hline Central calcification & 0,42 \\
\hline Peripheral calcification & 0,54 \\
\hline
\end{tabular}



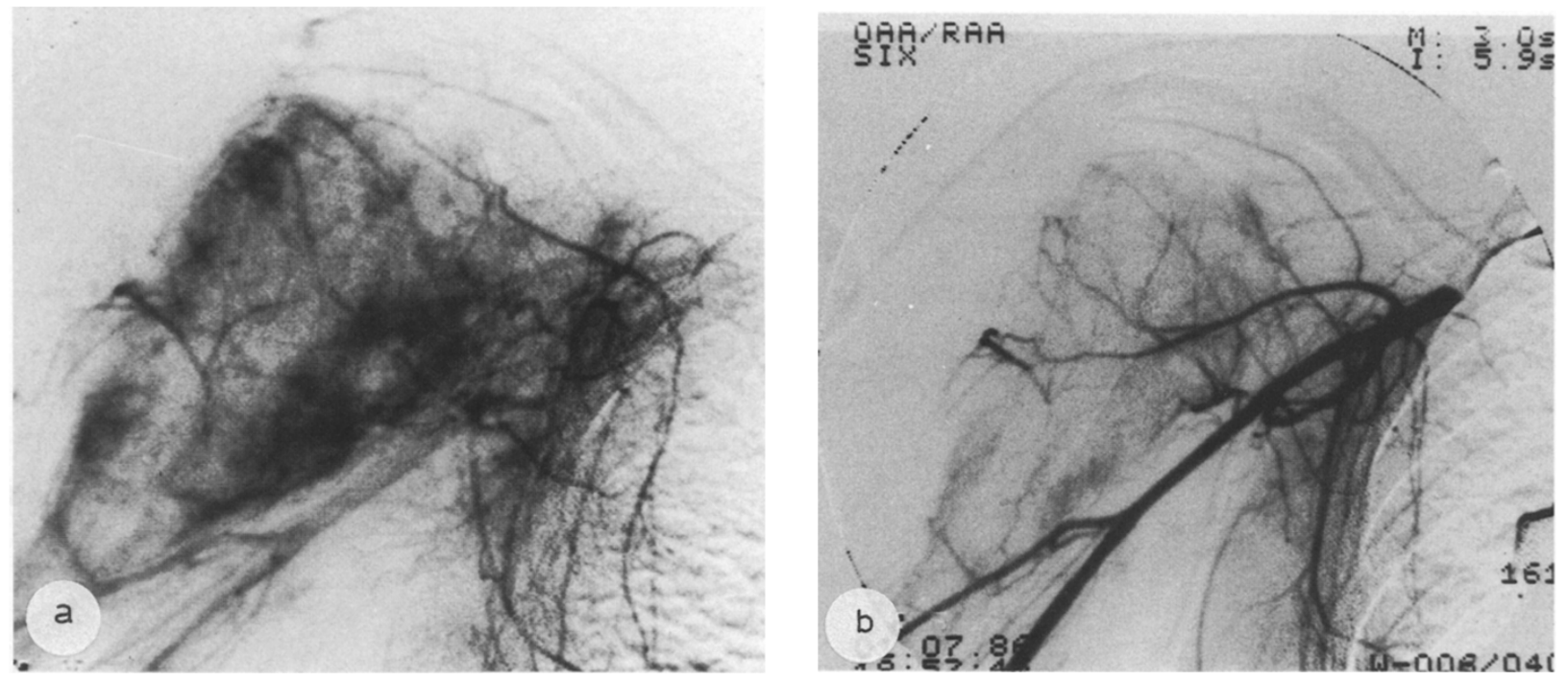

Figure 1. Poor tumor necrosis (Malvligit-grade III) and poor angiographic response (grade III angiography). Chondroblastic osteosarcoma of proximal humerus. (a) Angiography before chemotherapy. Prominent areas of neovascularity, with intense staining. (b) Post-chemotherapeutic angiography shows persistence of several hypervascular foci.
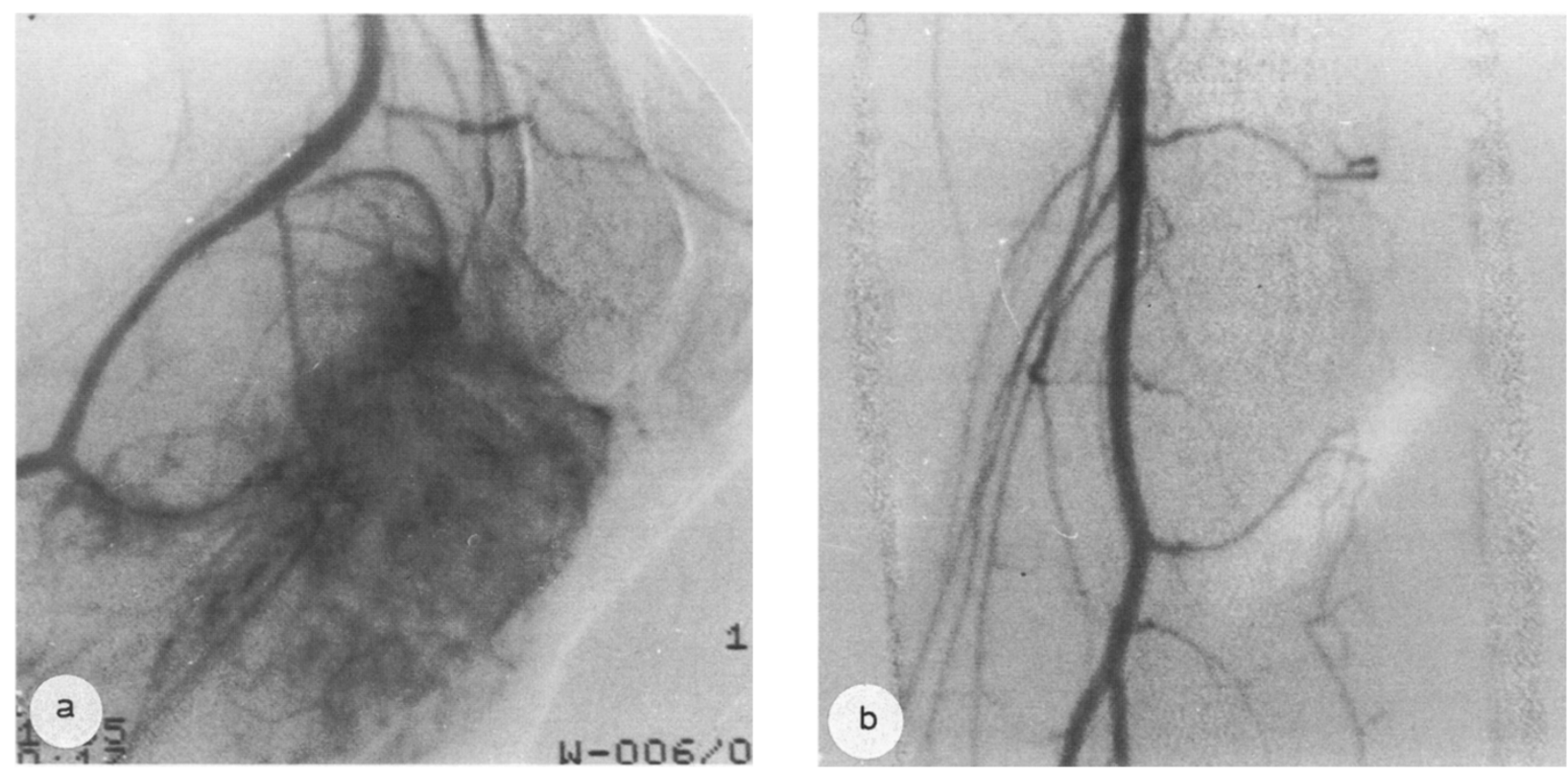

Figure 2. Good response to chemotherapy: massive tumor necrosis (Mavligit-grade V) correlates with the angiographic response to treatment (grade IV angiography). (a) Angiography pre-chemotherapy, showing intense neovascularity. (b) Postchemotherapeutic angiography shows complete disappearance of the abnormal findings 

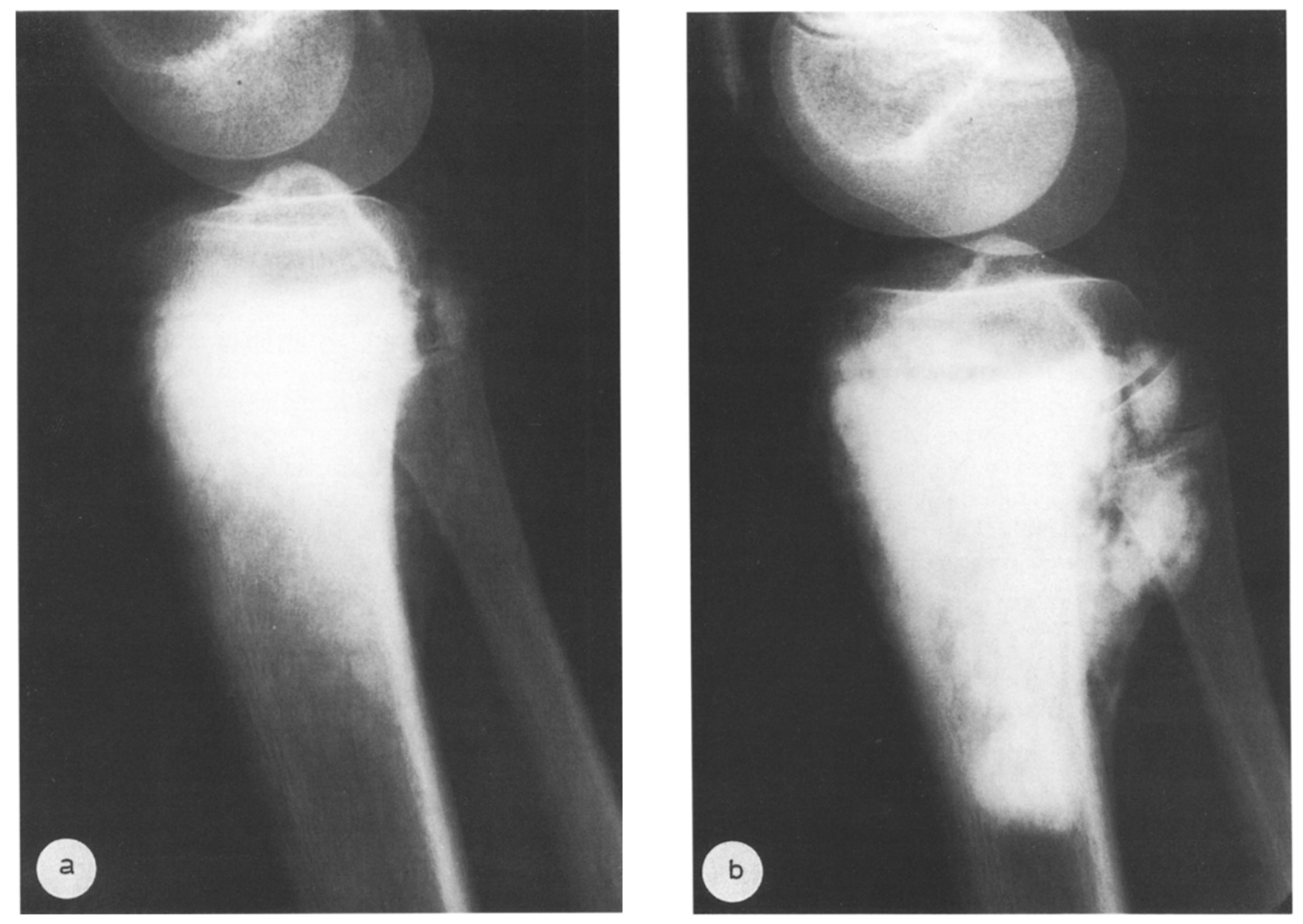

Figure 3. Good response to chemotherapy was achieved, with $100 \%$ tumor necrosis in the resected specimen (Mavligit-grade V). Osteoblastic osteosarcoma of the proximal tibia. (a) Pre-chemotherapy lateral view. (b) Post-chemotherapy. Marked increase in extra-osseus calcifications (grade IV in conventional radiography). 

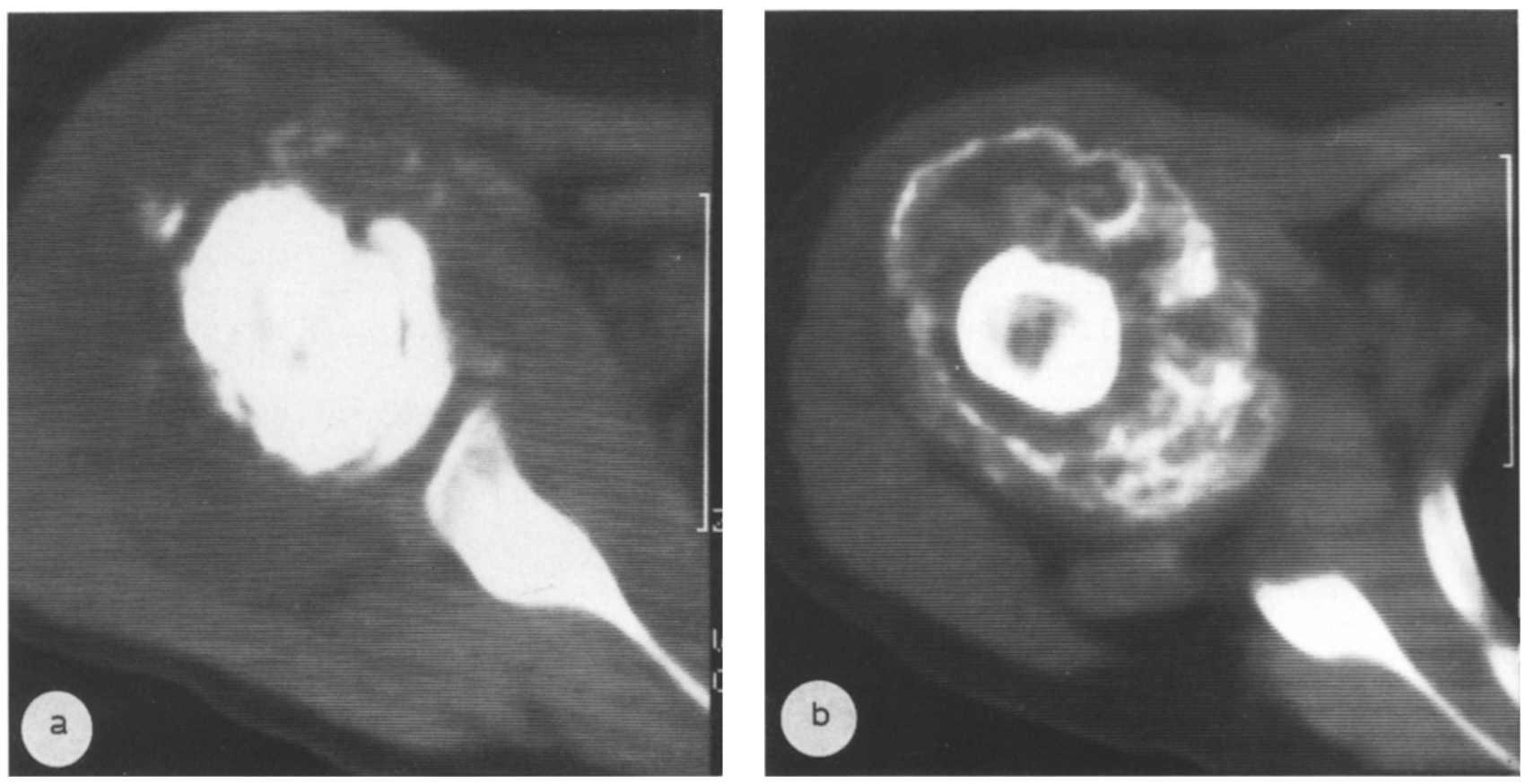

Figure 4. Same patient as in Fig. 1. Good radiological response ('egg-shell' calcification) correlates poorly with tumor necrosis in the resected specimen. (a) Prechemotherapy CT-scan. A huge soft-tissue mass is evident. (b) Post-chemotherapeutic CT-scan. Marked increase in peripheral calcification and partial decrease in soft-tissue mass. 